\title{
Towards a Legal Dictionary Dutch-Limburgish: Preferences and Opportunities
}

\author{
Conrad J.P. van Laer, Limburgish Academy Foundation, Maastricht, \\ The Netherlands (coenvanlaer9@gmail.com)
}

\begin{abstract}
Limburgish is a regional language in the Limburg region consisting mostly of the Belgian and Dutch provinces of Limburg. The discussion will be on the Dutch province of Limburg where Limburgish has received some legal recognition as a language. It is desirable to have a Dutch-Limburgish legal dictionary to communicate Dutch law, although Limburgish legal terminology is not a working legal language in any legal system.

Special structures and data are needed to collect accessible contents for a Dutch-Limburgish legal dictionary. However, there is no blueprint to create a bilingual legal dictionary for a single jurisdiction. Therefore, this paper first considers some options for the design of the intended dictionary before going into possible sources for Dutch and Limburgish data.

The concluding remarks deal with the immediate challenges to be overcome before reaching the production stage of a useful and fully-fledged Dutch-Limburgish legal dictionary.
\end{abstract}

Keywords: SPECIALIZED DICTIONARIES, SUBJECT FIELD DICTIONARY, LEXICOGRAPHY, MULTILINGUAL DICTIONARIES, BILINGUAL DICTIONARIES, EQUIVALENCE, CULTURE-DEPENDENT DOMAINS, LEGAL LANGUAGE, DUTCH, REGIONAL LANGUAGE, LIMBURGISH

Opsomming: Op weg na 'n regswoordeboek Nederlands-Limburgies: Voorkeure en geleenthede. Limburgies is 'n streektaal in die Limburg-streek wat meestal uit die Belgiese en Nederlandse provinsies van Limburg bestaan. In die bespreking word gefokus op die Nederlandse provinsie van Limburg waar Limburgies reeds 'n bietjie wetlike erkenning as taal ontvang het. Alhoewel die Limburgiese regsterminologie nie 'n funksionerende regstaal in enige regstelsel is nie, is dit wenslik om oor 'n Nederlands-Limburgiese regswoordeboek te beskik om die Nederlandse reg weer te gee.

Spesiale strukture en data word benodig om toeganklike inhoud vir 'n Nederlands-Limburgiese regswoordeboek te versamel. Daar is egter geen konsep vir die skep van 'n tweetalige woordeboek vir 'n enkele jurisdiksie nie. Daarom word die opsies vir die ontwerp van die beplande woordeboek eers in hierdie artikel beskou voordat moontlike bronne vir Nederlandse en Limburgiese data bespreek word.

Ter afsluiting word daar gekyk na die onmiddellike uitdagings wat oorkom moet word voordat 'n bruikbare en volledige Nederlands-Limburgiese regswoordeboek saamgestel kan word.

Sleutelwoorde: GESPESIALISEERDE WOORDEBOEKE, VAKWOORDEBOEK, LEKSIKOGRAFIE, MEERTALIGE WOORDEBOEKE, TWEETALIGE WOORDEBOEKE, EKWIVALENSIE, 


\section{Introduction}

Limburgish is a regional or minority ${ }^{1}$ language spoken in the Limburg region, which consists of the Belgian and Dutch provinces of Limburg. Linguistically, Limburgish differs from the neighbouring languages Dutch and German because of its own phonology, grammar, and vocabulary. ${ }^{2}$ The recognition the language received in 1997 under Part II of the European Charter of Regional or Minority Languages (ECRML) ${ }^{3}$ is confined to the Dutch province of Limburg. The focus in this paper will therefore be on Limburgish in the South-Eastern province of Limburg in the Netherlands unless otherwise specified.

Since lawyers often need to explain the meaning of legal terminology to clients during consultations, it may be assumed that Limburgish is used in conversations about legal matters. Moreover, as part of the recognition of Limburgish under Part II of the ECRML, in particular under Article 7(1)(d), the Dutch government is currently obliged to facilitate and/or encourage the use of Limburgish, in speech and writing, in public and private life. Public life covers the domains of government and the courts. ${ }^{4}$ In the longer term, recognition of Limburgish under part III could take place. A part III recognition would include more robust measures for the language to be used in the administration of justice (De Groot 2019: 121-122).

Currently, Limburgish is not used in any jurisdiction. The Dutch province of Limburg is fully dependent on the Dutch jurisdiction which means that Dutch is the only official language of government for this province. Limburgish is not a legal language and strictly speaking legal sources in Limburgish do not exist. Nevertheless, useful translations of Dutch legal terms may be found in non-legal Limburgish sources. These Limburgish equivalents most likely do not cover all Dutch legal terms, but a Dutch-Limburgish legal dictionary could help to give Limburgish access to the legal domain. The intended Dutch-Limburgish legal dictionary will expand the usage of Limburgish in the legal sphere and will fulfil the prevailing obligation under part II ECRML.

However, to date there is no Dutch-Limburgish legal dictionary which could help legal professionals to inform their clients about Dutch law in Limburgish. A Dutch-Limburgish legal dictionary could help to make current Dutch law more comprehensible, thereby contributing to the propagation of Limburgish legal terms.

A bilingual dictionary is a tool pairing Dutch legal terminology with Limburgish legal terminology. Both parts of the dictionary must be presented in such a way that they are useful for the prospective users i.e., the target group of the dictionary. This paper takes account of that reality in its treatment of the special structure of the dictionary and the possible sources for the Dutch part and the Limburgish part of the dictionary. In addition to setting out preferences for the possible design and contents of a Dutch-Limburgish legal diction- 
ary, this paper assesses the opportunities for completing such a labour-intensive process successfully.

\section{Design of the dictionary structure}

A legal dictionary is not a simple word list in alphabetical order but primarily a linguistic tool consisting of many elements, for example Dutch entries or entry words, definitions, Limburgish equivalents, grammar, syntax, collocations, examples and explanatory sentences. Obviously, Dutch entries and their Limburgish equivalents are the compulsory elements of each dictionary article. Then, the compulsory and facultative elements will have to be structured to shape the whole bilingual dictionary article and to make the dictionary useful. However, there is no blueprint available to produce a Dutch-Limburgish legal dictionary. This means that the design of the structure of the intended dictionary is an important step. To this end, determining the target group of intended users of the dictionary is important as the design of the dictionary must correspond with the needs of those users.

First of all, the target users and their needs must be identified. Professional lawyers who want to discuss Dutch law and their Limburgish speaking clients will be the main target groups of the intended legal dictionary. The intended audience is bilingual since monolingual speakers are rare in modern Limburg. It is estimated that 70-75 percent of a population of about one million in Dutch Limburg speaks Limburgish. ${ }^{5}$ Although most people in Dutch Limburg are able to speak both Dutch and Limburgish, when it comes to justifying themselves before a court of law, they may feel the need to express themselves in Limburgish, the language which is emotionally closest to them or in which they have greater fluency.

Today, documents in Limburgish do not have legal effect so lawyers may not look to the intended dictionary to help with the drafting in Limburgish, but rather to communicate with laypeople preferring Limburgish, particularly, to explain Dutch legal concepts to those clients. Consistently, the intended dictionary does not so much aim to produce texts in Limburgish but to improve the understanding of Dutch legal terminology used in conversations in Limburgish. Therefore, the intended dictionary does not have to include any Limburgish translations of Dutch legal definitions as these are too-complicatedto-explain Dutch terms. In addition, it is not necessary to prescribe any uniform terminology, for example by excluding some synonyms or by neglecting language or spelling variants. The main function of the dictionary is communicative as it aims to help laypeople to understand Dutch law in Limburgish without having to decipher legalese.

As there is no existing bilingual legal Dutch-Limburgish dictionary we have no models to guide us, but there is an interesting bilingual legal dictionary for another regional language in the Netherlands. The 'Juridysk Wurdboek' is a Dutch-Frisian legal dictionary, which was published two decades ago for an 
audience of lawyers and civil servants using legalese professionally (Duijff 2000: 11). This reference work will provide inspiration for the design of the intended Dutch-Limburgish legal dictionary. It must be noted though that Frisian is an official language of government while Limburgish does not share that status yet.

The 'Juridysk Wurdboek' is a bilingual dictionary that is unidirectional, allowing translations from Dutch to Frisian. The index from Frisian to Dutch is a simple word list in alphabetical order that refers the users back to the dictionary entries to ensure that they can easily identify the source terms. This macrostructure could be a starting point for the arrangement of the entries or entry words in the intended Dutch-Limburgish legal dictionary. ${ }^{6}$

The microstructure of the 'Juridysk Wurdboek' could be a starting point as well. The microstructure of a dictionary describes the arrangement of the information provided by the dictionary articles. Obviously, the macrostructure must be aligned to the microstructure of the envisaged dictionary so the index of the 'Juridysk Wurdboek' reflects the dictionary entries. These entries consist of one word only. Compound terms, for example the Dutch term 'buitenvervolgingstelling', are single words and can be accepted as entries. It is noteworthy that to facilitate user access, multi-word expressions for legal concepts are not included as separate entries but may be added to the main entries. Multiword terms that are not featuring as separate entries have the result that dictionary articles frequently refer to separate entries that may include fixed expressions and example sentences as well (Duijff 2000: 13-15).

Given that Limburgish is not on an equal footing with the Frisian language, the dictionary must be compiled for oral communication with laypeople in the first place. Spoken legal language makes the insertion of pronunciation aids more important than it would be in dictionaries for authors of formal documents. The provision of pronunciation guidance will prevent mistakes made by users in oral communication, especially as far as lower frequency terms are concerned (Tihelková 2006: 117). Preferably, the intended dictionary including the pronunciation guidance will be digital. ${ }^{7}$ Digital voice output will be more user-friendly for lawyers and laypeople than the International Phonetic Alphabet (IPA) in a printed dictionary. Ideally, bilingual conversations on legal matters will be translated almost real-time on a phone or tablet. ${ }^{8}$

It is difficult, sometimes, if not impossible to dislodge established usage. This is perhaps the main reason that most lexicographers acknowledge that dictionaries must register actual word usage. Accordingly, the Dutch-Frisian dictionary presents the contemporary Frisian legal language except where an exception had to be made and a neologism had to be derived from Old Frisian sources. ${ }^{9}$ The second exception to the accepted principle of describing actual word usage is that the dictionary does not list synonyms for Frisian terminology. The reason for this choice is that the dictionary aims to be prescriptive to avoid any ambiguity of written terms and to achieve a uniform legal terminol- 
ogy (Duijff 2000:19-20). However, this consideration does not apply to Limburgish legal terms which have no claim to any legal consequences.

\section{Sources for Dutch legal terms}

The design of the Dutch-Limburgish legal dictionary must be tailored to the needs of the target group of professional lawyers, such as judges or civil servants, who want to explain Dutch law to laypeople who prefer Limburgish. Presumably, professional lawyers are aware of most if not all definitions of Dutch legal terms, so accurate and verifiable Dutch definitions are only needed to ascertain that these dictionary users have found the correct term. Definitions are not needed to assess degrees of equivalence between Dutch terms and Limburgish terms since that equivalence is always full: conceptual distinctions are absent as both languages relate to the same Dutch legal system, whose only binding legal terminology is in the Dutch language.

Arguably, most Limburgish translations of legal definitions would be useless in conversations as legal definitions are too complicated to help laypeople to understand Dutch law. The main purpose of the Dutch-Limburgish dictionary is not so much the transfer of legal concepts and their specific definitions but the explanation of the use of Dutch legal terms by means of Limburgish translations. Preferably, these translations will feature in illustrating sentences, like the following ones: 'D'n avvekaot vroog de rechter um straofvermindering' (The lawyer asked the judge to grant a mitigation of a penalty); 'Volges de euvereinkoms höb iech aonspraok op ein daarde vaan de wins' (Pursuant to the agreement I have a claim on one third of profit); 'Dit ligk boete zien competentie' (This is beyond his competence); 'Krach vaan wèt verkriege' (To gain force of law).

To compile a comprehensive legal dictionary Dutch-Limburgish, Dutch legal terminology should be the starting point. Obviously, terms which are exclusively legal must be included in the intended dictionary as they must be explained in everyday language. In addition, common words like 'divorce' or 'contract' must be included since they can acquire a specific meaning in a legal context. Although it may be problematic to answer the question how legal terms can be distinguished from non-legal terms, ${ }^{10}$ it may be necessary that sources for Dutch terminology cover both terms and common words used in a legal context.

Both terms and common words used in a legal context are available in a small number of legal dictionaries which are relevant sources for Dutch legal terms. The most recent edition of the Dutch legal dictionary, the title of which still includes the name of its founder (Van Caspel and Damen 2016), is an extensive source of current Dutch legal terminology covering a substantial number of collocations ${ }^{11}$ in many legal domains. To clarify legal terms, the dictionary provides many definitions or explanations and it frequently refers to relevant legal provisions. In addition to this work, another comprehensive 
Dutch legal dictionary exists (Khan 2018). Both dictionaries have not been based on any accepted or representative standard corpus of Dutch legal documents. A comparison of both sources should take place to assess their exact scope and academic quality. ${ }^{12}$ This means that the contents of the intended dictionary must be derived from one or two traditional legal dictionaries for Dutch law which may be supplementary to some extent.

\section{Sources for Limburgish legal terms}

As stated earlier, Limburgish legal terms cannot be found in legal documents since Limburgish is not an official language used in the legal domain in any jurisdiction. Currently, there is no Limburgish legal language as a source for legal terminology. Therefore, sources must be traced that will provide Limburgish terms that can be easily recognized and accepted as legal terms corresponding to Dutch equivalents.

The first source to be considered is the growing corpus of Limburgish texts collected by the Limburgish Academy. ${ }^{13}$ The Limburgish Corpus reflects the written usage from 1775 to the present. ${ }^{14}$ However, the Limburgish Corpus is not aligned and bilingual as it does not include similar legislative or judicial documents in both Dutch and Limburgish. Therefore, Dutch legal dictionaries of sufficient quality are needed to assess possible translations of Dutch legal terms from the Limburgish Corpus. From 2021, the process of mining this expanding Limburgish Corpus will be facilitated as metadata will provide access to different types of texts that can be mined for Limburgish terms with some legal connotation. Firstly, the corpus will be tagged for text topics, including 'legal'. This label is used for everyday speech referring to legal topics. Secondly, the corpus is tagged for 'genre' (nonfictional prose) and subgenre (like minutes of meetings, policy statements, and regulations). The use of the language in these more formal and administrative domains could also help to trace Limburgish terminology that has a more legal connotation.

The size of the Limburgish Corpus will likely suffice to provide translations for high frequency everyday terminology and to extract example sentences to illustrate their usage in speech referring to legal contexts. It is expected that the Limburgish Corpus will cover terminology such as 'echsjeiing' (divorce), 'besjikking' (decision), 'verdachde' (suspect) or 'perces-verbal' (report). These examples show an etymological relationship between Limburgish and Dutch terms, but this relationship is not necessary. The following examples suggest different origins: 'aonpakke' (bring charges against), 'beveurmunde' (have custody over), 'proofrech' (right of judicial review), 'toch' (usufruct) and 'tous' (lease term). More importantly, Limburgish terms may be embedded in multi-word expressions that will include collocations, like 'Zie make 't gesjèl aonhengeg bij de rechbaank' (They submit the dispute before the court).

Novels and other secondary sources in the Limburgish Corpus will document colloquial speech, but it is less certain whether it will include enough low 
frequency terms, which are exclusively legal, for example 'comparant' (person appearing before the court etc.) or 'obligatoir' (obligatory). In addition, compound terms like the Dutch 'buitenvervolgingstelling' or 'ingebrekestelling' are terms illustrating the gap between everyday language and legal language (Van den Bergh 1979: 54). Therefore, it will be assumed that the Limburgish Corpus will not provide enough terms to translate all Dutch terms that are present in the standard legal dictionaries.

Additional methods are needed to create Limburgish legal terms which are low frequency terms that do not feature in everyday language and that are not attested in the Limburgish Corpus. Other solutions found in previous research (De Groot 2012: 541-544) ${ }^{15}$ will be discussed here: preserving the original term, paraphrasing, and creating neologisms.

Preserving the original Dutch term does not provide a Limburgish equivalent revealing anything about the meaning of that Dutch term. Preserving the Dutch term would not make it more familiar or easier for Limburgish speakers to understand it. This rejection of the first solution includes 'transliterations' assimilating the phonology of a Dutch legal term into the phonological system of Limburgish (Stephens and Boyce 2014: 305) to make borrowings more like the native words of this target language. For example, transcribing 'descente' as 'dessânte' is no translation and will not be very helpful to understand the legal concept involved.

Paraphrasing is the second solution and consists of describing Dutch terms using different words. Paraphrasing is driven by precision, and the descriptive method might help to explain the essential characteristics of the concept (Fuglinszky and Somssich 2020: 760). This approach may be effective, provided the intended meaning has been spelled out in neutral language and terms have been omitted (Šarčević 2000: 252). However, a paraphrase consisting of several common words could be too long or too complex to make it easy to understand the exact meaning of the original Dutch legal term. This means that paraphrasing should be limited.

The third subsidiary solution, the neologism, ${ }^{16}$ looks more promising. Neologism means the artificial creation of a new term in the target language that would obviously not have a fixed meaning therein, and so it is perfectly suited to express the special nature of the concept of the source legal system, which lacks approximate equivalents in the target legal language (Fuglinszky and Somssich 2020: 762). Although neologisms are not in use in Limburgish yet, they could prove to provide useful new terms if they reveal the original Dutch term to some extent. By contrast, invented words for arbitrary sounds like 'blubs' have no legal connotation, are not transparent and fail to provide any information.

Finally, candidate equivalents might be found in Limburgish documents dating from the period before 1600 when Limburgish was used as a legal language of government. ${ }^{17}$ However, accurately transcribed legal documents up to 1600 need to be evaluated by Middle Dutch and Middle Limburgish linguis- 
tic experts to ascertain the text's linguistic provenance. This may be an expensive, time-consuming procedure. Another caveat for using possible equivalents from older texts is that most professional lawyers will not be familiar with Limburgish terms before 1600 even though to some extent the use of archaisms and obsolete words is typical of legal language. In this case most terms before 1600 will refer to outdated legal systems or local situations. Linguistically, these pre-1600 terms will likely not be recognizable for Limburgish-speaking laypeople. ${ }^{18}$

The intended dictionary will not be prescriptive and will therefore include synonyms. It is certainly possible that more Limburgish candidates could be deemed viable options to translate Dutch legal terms. However, the intended dictionary should provide Limburgish terms which can be easily recognized as legal terms translating Dutch equivalents. In those cases, the primary selection criterion will be that the Limburgish terms are memorable and self-explanatory to facilitate their spread and their usage. Suitability of Limburgish terms according to this criterion will be assessed based on two requirements. Firstly, the frequency of the usage of the term in the Limburgish Corpus. Frequent usage of a word will likely facilitate its recognition and its acceptance by a lay audience and possibly a professional audience. Secondly, if feasible, a user group of lawyers and paralegals will be consulted, via questionnaires, about the suitability and acceptability of proposed Limburgish legal translations for Dutch legal terminology.

Finally, attention should be paid to one possible complicating factor in creating a Limburgish legal terminology. Limburgish is not only used in the Dutch province of Limburg but also in the province of Limburg under Belgian sovereignty, where Dutch is also used as a language of government. It cannot be excluded that at some point another Dutch-Limburgish legal dictionary will be developed for the Dutch legal terms used by the Belgian jurisdiction. However, legal terms are system-bound because they are related to and embedded in legal systems. For this reason, the dictionary compiler translating Dutch legal terms from the Netherlands into Limburgish should try to avoid similarities with Belgian legal terms. This requires that the choice of Limburgish terms for the jurisdiction in the Netherlands must be based on a comparison of Dutch and Belgian law in order to express the differences between both legal systems. For example, the Limburgish translation of the Dutch term used in the Netherlands 'officier van justitie' (public prosecutor) should differ from the one for its Belgian counterpart 'procureur des konings' (Crown prosecutor) (Knap-Dlouhá and Škrlantová 2008: 86-87). These terms belong to two legal systems using Dutch as a legal language. Introducing only one Limburgish equivalent would cover up the differences involved.

\section{Feasibility: preferences and opportunities}

It is unrealistic to plan a comprehensive and explanatory legal dictionary 
Dutch-Limburgish to be finished in less than five, maybe ten years unless some financial resources are made available to a team of professionals. Therefore, one should consider a less ambitious pilot project to test a provisional workflow, ${ }^{19}$ to develop clear instructions for the dictionary compilers, to specify the data and the structures needed for the intended dictionary, and to get feedback from users in order to improve the initial data and structures. The pilot testing should be limited to one legal subdomain within larger areas, for example criminal law, allowing decisions to be made for the full-fledged production phase that is compliant with high quality standards.

The pilot project should focus on a limited number of primary Dutch sources, in particular dictionaries, to test whether they are compatible with the microstructure of the intended dictionary. This compatibility could be a problem since many multi-word entries appear in Van Caspel and Damen 2016, the main source for Dutch legal terms, while multi-word terms are absent in the entries of the 'Juridysk Wurdboek', the dictionary which provides the inspiration for the design of the intended Dutch-Limburgish legal dictionary. In addition, it should be assessed which Dutch terminology is relevant and sufficient not only to extract some Limburgish equivalents and illustrating sentences from the corpus of Limburgish texts, but also to show for which Dutch entries translations are missing.

For possible Limburgish terminology, the pilot project should explore to what extent possible candidates, multi-word expressions and collocations can be found in the Limburgish Corpus. ${ }^{20}$ This exploration is important as it has been argued above that it is almost impossible to create Limburgish terms which are exclusively legal but not appearing in everyday language. If the Limburgish Corpus Dictionary provides only a very limited number of Limburgish candidate equivalents for legal terms, it could become difficult to maintain that the intended dictionary will help legal professionals to inform their clients about Dutch law in Limburgish. To fill this gap, time-consuming paraphrasing will be needed since preserving the original Dutch term is not an option while creating acceptable neologisms will be complicated.

Apart from the data needed for the intended dictionary, attention should be paid to its compilation and, after its completion, its publication and dissemination. Publication in book form is an option, as is making it available online. For an online version, the software tools may provide pronunciation guidance as a facultative element of the dictionary. By contrast, an accessible search interface for the end users is a compulsory element. Ideally, the dictionary must be comprehensible enough to answer the basic queries of a nonexpert while the legal practitioners must feel confidence in using its translations (Poon 2010: 90). Preferably, to reach both target groups and to get their feedback, the Limburgish Corpus Dictionary will be expanded to include the Limburgish Legal Dictionary. ${ }^{21}$ Incorporating a full-fledged legal terminology in the Limburgish Legal Dictionary would be an important step towards law- 
yers drafting documents in Limburgish thereby anticipating the enhanced protection of this regional language (De Groot 2019: 119-125).

\section{Acknowledgements}

This paper and the research behind it would not have been possible without the exceptional support of the following experts: Dr. Mairtin Mac Aodha, Lawyerlinguist; Dr. Elena Chiocchetti, Eurac Research; Drs. Pieter Duijff, Fryske Akademy; Prof. Gerard de Groot, Maastricht University; Dr. Yuri Michielsen, Limburgish Academy; Dr. Sandro Nielsen, Centre for Lexicography at the Aarhus University. I am very grateful for their insightful comments on an earlier version of this paper.

\section{Endnotes}

1. The term "minoritized" language may be used in preference to "minority" because it draws attention to the unequal power relationships between languages. Limburgish does not refer to any regional variation of Dutch spoken in Dutch or Belgian Limburg.

2. Limburgish Language: https://limburgs.org/en/limburgish/

3. ECRML:

https://www.coe.int/en/web/conventions/full-list/-/conventions/rms/0900001680695175

4. Cf. Explanatory Report to the European Charter for Regional or Minority Languages Strasbourg, 5.XI.1992 https://rm.coe.int/16800cb5e5 p. 10: (62) "The charter does not lay down precise objectives in this respect but is content to call for an effort of promotion." However, the Dutch government has been negligent in its implementation of Part II obligations and no request for recognition under Part III seems to be forthcoming.

5. Contemporary presence: https://limburgs.org/en/limburgish/

6. An additional Dutch-English index could be derived from (Van den End 2016).

7. Dictionaries are made available in digital format for several reasons. Digital editions eliminate the cost of publishing print dictionaries and allow updates to the dictionaries' content. Thirdly, publishing online and in apps allows users instant access to dictionaries on devices they carry everywhere on their person, making them much more convenient and portable. See e.g., Andrews and Prys 2016: 10.

8. Cf. Google's Translate app which suggests this is technically possible, for many languages: https://support.google.com/translate/answer/6142474?hl=en\&ref_topic=7011659 Cf. the interactive online tool produced by the Living Tongues Institute for Endangered Languages. This device digitally preserves words and phrases, and allows the user to hear high-quality audio recordings of their language, as well as record and upload new content and images: https://livingtongues.org/talking-dictionaries/

9. Old-Frisian legal terms refer to concepts from a legal system that is completely different from the modern Dutch system. In addition, Old-Frisian legal terms are outdated (Duijff 2000: 17).

10. There is no clear boundary. To a certain extent, it can be argued that any matter may be the subject of legal rules but obviously everyday events such as buying a loaf of bread are not essentially legal acts. To find out whether the context is legal, it is problematic to steer a mid- 
dle course, but it may help that the context explicitly refers to situations involving disputes or lawyers.

11. An analysis of collocations in Dutch legal language has been carried out on the dictionary 'Fockema Andreae's juridisch woordenboek' (Tryczyńska 2014).

12. Accepted or representative standard lists of basic or most frequently used Dutch legal terms are not available. The Justice Thesaurus offers standard keywords that may be useful to identify Dutch legal terminology, but this Thesaurus is not complete: e.g., 'obligatoir' is missing. More Dutch legal terms could be found in selected legislative documents, as listed in the Introduction of the 'Juridysk Wurdboek' (Duijff 2000: 20-22).

13. https://limburgs.org/en/corpus/Within the Limburgish Corpus the contemporary spelling of the Maastricht variety is linked to all other existing spelling variation in other Limburgish dialects.

14. See https://limburgs.org/en/corpus/ and Michielsen-Tallman et al. 2017.

15. It is possible to distinguish more techniques: Kozanecka et al. 2017: 88.

16. Seven criteria to assess neologisms have been listed: Mac Aodha 2018: 295.

17. Prof. Dr. Louis Berkvens stated that after 1600 more foreign elements were included in Limburgish legal sources.

The Meuse-Rhineland region was already fragmented politically in the Middle Ages and was divided even further from 1600 due to raids from neighbouring countries. The new rulers introduced their languages for administration and justice in their Limburgish territories. Depending on the occupying power, French, Dutch, or High German were used as languages of government: https://limburgs.org/en/limburgish/

18. For example, 'bauduyn', a legal term before 1500 (for 'fine' in English), could be deemed an obscure term; cf. De Maasgouw 1881, p. 428 second column. Available:

https://resolver.kb.nl/resolve?urn=dts:2394003:mpeg21:0004

19. Cf. Chiocchetti et al. 2013: 9-11: The terminology workflow.

20. Abbreviations could be excluded from translating into Limburgish. Cf. Duijff 2000: 15.

21. https://limburgs.org/en/dictionary/ Filters for legal domains could make the build-in legal dictionary accessible as a separate unit. These filters must be based upon a predefined classification using an established division of the legal domain into subdomains such as criminal law etc.

\section{References}

\section{A. Dictionaries}

Duijff, P. 2000. Juridisch woordenboek Nederlands-Fries met een index Fries-Nederlands. Groningen/ Leeuwarden: Fryske Akademy/Martinus Nijhoff. Available: https://taalweb.frl/wurdboekportaal

Khan, W. 2018. Groot juridisch woordenboek: Beschrijvende definities van termen binnen de Nederlandse rechtspraktijk; inclusief een Engelse vertaling van de termen en verwijzingen naar relevante jurisprudentie. Den Haag: Sdu Uitgevers.

Van Caspel, R.D.J. and M.P. Damen. 2016. Fockema Andreae's juridisch woordenboek. 16th revised edition. Groningen: Wolters-Noordhoff. Also published online: https:/ / www.vandale.nl/fockema-andreaes-juridisch-woordenboek-nu-online 
Van den End, A. 2016. Juridisch-Economisch lexicon NL-EN. The Legal and Economic Lexicon. 6th edition. Deventer: Wolters-Kluwer. Available: https://www.gatewaywoordenboeken.nl/Start-159.html

\section{B. Online databases}

Justice Thesaurus. 2019. Research and Documentation Centre: Knowledge Centre in the Field of the Dutch Ministry of Justice and Security, version 2019. Available: https://english.wodc.nl/documents/regulations/2020/11/08/justice-thesaurus-version-2019 or in Dutch: Justitiethesaurus, versie 2019. Available: https://www.wodc.nl/documenten/regelingen/2020/11/18/justitiethesaurus-versie-2019

\section{Other literature}

Andrews, T. and G. Prys. 2016. Terminology Standardization in Education and the Construction of Resources: The Welsh Experience. Education Sciences 6(2): 1-15. Available: https://www.mdpi.com/2227-7102/6/1/2

Chiocchetti, E., N. Ralli, V. Lušicky and T. Wissik. 2013. Spanning Bridges between Theory and Practice: Terminology Workflow in the Legal and Administrative Domain. Comparative Legilinguistics 16: 7-22. Available: https://pressto.amu.edu.pl/index.php/cl/article/view/6427/6449

De Groot, G-R. 2012. Legal Translation. Smits, J.M. (Ed.). 2012. Elgar Encyclopedia of Comparative Law: 538-549. 2nd edition. Cheltenham: Edward Elgar.

De Groot, G-R. 2019. European Charter for Regional and Minority Languages. Schoonheim, T. and J. van Hoorde (Eds.). 2019. Language Variation: A Factor of Increasing Complexity and a Challenge for Language Policy within Europe. Contributions to the EFNIL Conference 2018 in Amsterdam: 115-128. Budapest: Research Institute for Linguistics, Hungarian Academy of Sciences. Available: http://efnil.org/documents/conference-publications/amsterdam-2018/EFNIL2018-18DeGroot.pdf

Fuglinszky, Á. and R. Somssich. 2020. Language-bound Terms - Term-bound Languages: The Difficulties of Translating a National Civil Code into a Lingua Franca. International Journal for the Semiotics of Law 33: 749-770. Available:

https://link.springer.com/article/10.1007\%2Fs11196-020-09704-x

Knap-Dlouhá, P. and M. Škrlantová. 2008. Rechtstaallandschap: Intralinguale vertaling van juridische terminologie bij de didactisering van juridische vertaling. Hrnčírová, Z., E. Krol, K. Mercks, J. Pekelder en J. Ultzen: Praagse perspectieven 5: Handelingen van het Regionaal Colloquium Neerlandicum van Midden-Europa aan de Karelsuniversiteit te Praag op 20, 21 en 22 September 2007: 79-90. Praag: Universitaire Pers. Available: https://www.dbnl.org/tekst/_pra004200801_01/colofon.php

Kozanecka, P., A. Matulewska and P. Trzaskawka. 2017. Methodology for Interlingual Comparison of Legal Terminology: Towards General Legilinguistic Translatology. Poznań: Contact. Available: https://repozytorium.amu.edu.pl/bitstream/10593/21240/1/Dissertationes\%2011 \%202017\%20Kozanecka\%20Matulewska\%20Trzaskawka.pdf 
Mac Aodha, M. 2018. Lexicographie, traduction et langues minoritaires: le cas de l'irlandais au sein de l'Union européenne. Doctoral Dissertation. Strasbourg: University of Strasbourg. Available: https://tel.archives-ouvertes.fr/tel-02081060/document

Michielsen-Tallman, Y., L. Lugli and M. Schuler. 2017. A Limburgish Corpus Dictionary. Digital Solutions for the Lexicography of a Non-standardized Regional Language. Kosem, I., C. Tiberius, M. Jakubíček, J. Kallas, S. Krek and V. Baisa (Eds.). 2017. Electronic Lexicography in the 21st Century. Proceedings of the eLex 2017 Conference, Leiden, the Netherlands, 19-21 September 2017: 355-376. Brno: Lexical Computing. Available: https://elex.link/elex2017/wp-content/uploads/2017/09/paper22.pdf

Poon, W.Y.E. 2010. Strategies for Creating a Bilingual Legal Dictionary. International Journal of Lexicography 23(1): 83-103

Šarčević, S. 2000. New Approach to Legal Translation. Reprint. The Hague: Kluwer Law International.

Stephens, M. and M. Boyce. 2014. The Struggle for Civic Space Between a Minority Legal Language and a Dominant Legal Language: The Case of Māori and English. Mac Aodha, M. (Ed.). 2014. Legal Lexicography: A Comparative Perspective: 289-319. Farnham: Ashgate.

Tihelková, A. 2006. Theory and Practice of Czech Bilingual Specialized Dictionaries. Doctoral Dissertation. Prague: Charles University.

Tryczyńska, K. 2014. Collocaties in het juridisch woordenboek van Fockema Andreae: Een frequentieanalyse. Neerlandica Wratislaniensia 24: 93-106. Available: https://wuwr.pl/nwr/article/view/3037/2954

Van den Bergh, G.C.J.J. 1979. Recht en taal, preadvies. Deventer: Kluwer. 